\title{
Development of Manipulative Module of Algebraic Tiles for Quadratic Expressions and Equations
}

\author{
${ }^{1}$ Rozita Mohamed Radzuan and ${ }^{2}$ Marzita Puteh \\ ${ }^{1}$ Department of Mathematics, Faculty Science and Mathematics Sultan Idris Education University Tanjung Malim, Perak, Malaysia \\ ${ }^{2}$ Department of Mathematics, Faculty Science and Mathematics Sultan Idris Education University, Tanjung Malim, Perak, Malaysia
}

Correspondence Author: Rozita Mohamed Radzuan, Department of Mathematics, Faculty Science and Mathematics Sultan Idris Education University Tanjung Malim, Perak, Malaysia

Received date: 11 April 2018, Accepted date: 25 July 2018, Online date: 8 August 2018

Copyright: (c) 2018 Rozita Mohamed Radzuan et al., This is an open-access article distributed under the terms of the Creative Commons Attribution License, which permits unrestricted use, distribution, and reproduction in any medium, provided the original author and source are credited.

\begin{abstract}
The Manipulative Module of Algebraic Tiles is developed to help students understand the concepts in the Quadratic Expressions and Equations topic. This module is built based on the Sidek Module Development Model (SMDM). The percentage of expert's approval for this module is $86.7 \%$ and was certified by 3 experts. This module is designed for moderate- low Form Four achievers. The learning theories used in this module are Constructivism Learning Theory, Piaget Cognitive Theory, Bruner Learning Theory and Active Learning Theory. This module consist of seven units where Unit 1 is the introduction to Algebraic Tiles, Unit 2 and 3 are the revision of Algebraic Expressions and Linear Equations while Unit 4 to 7 are the units on the Quadratic Expressions and Equations topic. This module comes with homemade physical algebraic tiles. The development of this module is expected to help students convert abstract concept of the Quadratic Expressions and Equations topic into concrete manipulative objects, thus helping them enhance their understanding.
\end{abstract}

Key words: Manipulative Module of Algebraic Tiles Quadratic Expressions and Equations Algebraic Tiles Mathematical.

\section{INTRODUCTION}

The education system in Malaysia from the Age of Development Policy to the Age of National Vision Policy has undergone rapid changes in the provision of infrastructure, educational facilities and training [5]. However, Malaysia's achievements according to the Trends in International Mathematics and Science Study (TIMSS) which experienced a declination from 2003 to 2009 posed an issue of why is our education development not in line with the achievements of international students. The programme for International Student Assessment (PISA) 2009 stated that Malaysia was ranked 57th out of 74 participating countries with an average score of 404 compared to the countries in the Organization for Economic Cooperation and Development (OECD) scoring 496 and the average score of 450 internationally. Although there was an increase of 25 points on TIMSS 2015 as compared to TIMSS 2011, Malaysia is still benchmarking below the international average scores. Hence various initiatives have been outlined by the Ministry of Education of Malaysia (KPM) to ensure a better position for the coming TIMSS 2019. In this regard, the approaches of teaching and learning which are fun, tangible, hands- on and manipulative have to be carried out in the classroom so mathematics is not seen as a static field, with irregular rules, as well as many formulas and procedures to pass the exams [12]. This Manipulative Module of Algebraic Tiles is built to help students develop an understanding of the concepts in the Quadratic Expressions and Equations topic using manipulated algebraic tiles.

Problem Statement:

The mathematical achievement under the OECD national average score in TIMSS and PISA 2012 showed that there is a lack in the school's teaching and learning method. In PISA 2012, 51.8\% of students were in low achievement level compared to only $1.3 \%$ in high- level achievement. The report also notes three contributing factors to the low performance, which are the attitudes of students who did not answer conscientiously, too long wordy question formats and the teachers who prioritized in completing the syllabus and preparing students for public examinations hurriedly, rather than focusing on the student's understanding of each topics [6].

Algebra is important in the TIMSS content domain, covering 30\% within the TIMSS Mathematical Assessment Framework 2015. Average Malaysian achievement for the domain in the algebraic content is at a moderate level of 467 versus international benchmarking. High Order Thinking Skills (HOTS) is needed to generate the generation of human capital that practices a critical, categorical and innovative thinking culture [16]. Unfortunately, the study of Kestrel Education Consultants (UK) and 21 Century Schools (USA) found that high order thinking skills of Malaysian students is very low [6]. Chappell \& Struchens, [2] states the students' ability to understand algebra limited if students are not exposed to ideas and relations in algebraic expressions. Research had also shown that the use of Bar Model Method is a strategy used by teachers to help pupils to visualize the mathematical concepts and solve problems [8]. Thus, in this research the researcher developed the Manipulative Module of Algebraic Tiles for Quadratic Expressions and Equations topic using the concrete tool for abstract representation of algebra [12].

The purpose of this study is to build the Manipulative Module of Algebraic Tiles for the Quadratic Expressions and Equations topic. The objectives of the 
Citation: Rozita Mohamed Radzuan and Marzita Puteh. Development of Manipulative Module of Algebraic Tiles for Quadratic Expressions and Equations. Advances in Natural and Applied Sciences., 12(8): 33-35. DOI: 10.22587/anas.2018.12.8.6

study are as follows:

1. Develop the Manipulative Module of Algebraic Tiles for Quadratic Expressions and Equations topic for moderate- low achievers.

2. Examine the validity of the Manipulative Module of Algebraic Tiles.

Method of Research:

1.Types of Research and Research Approach:

The study is a quantitative study via the survey method using the module content validity form by Sidek Mohd Noah and Jamaludin Ahmad [15] as the instrument of study. The draft of the Manipulative Module of Algebraic Tiles is given to 3 teachers to screen the weakness of the module in terms of the implementation before the module is awarded to 3 experts to assess the validity of the content.

\section{Study Procedures:}

\section{The procedure of the study was as follows:}

Level 1- Development of draft of the Manipulative of Algebraic Tiles. This module is built on Sidek Module Development Model (SMDM). This approach model involves two stages for different purposes. The first stage is the preparation of the module and the second level is the stage of testing and evaluating the module.

Level 2- Draft of Manipulative Module of Algebraic Tiles is given to 3 mathematics teachers to see the smooth running of the module implementation. Teachers are given a form where they can express their opinions about the contents, the instructions, the activities and the feasibility of the module.

Level 3- The repaired form of the draft of Manipulative Module of Algebraic Tiles based on the comments given in Stage 2 will be given to 3 experts to determine the validity. The expert group are composed of a School Improvement Specialist Coaches (Sisc+) Mathematics of Klang District, a teacher with high expertise in mathematics high order thinking skills (HEBAT) and a mathematics teacher with a teaching experience more than 10 years. These experts were given the module content validity questionnaire developed by Jamaludin Ahmad [4]. The expert approximate percentage is calculated.

\section{Population and Sample:}

The population of this study was a moderate- low achieving students who received grades C, D, E and F during the Pentaksiran Tingkatan 3 (PT3) at a school in the Klang district. These students are placed in 8 classes of different stream. The pilot study sample involved 40 students from a class in which their mathematical achievement was moderate- low.

\section{Research Instruments:}

In this study, the researcher uses the Instructional Content Module Questionnaire by Jamaludin Ahmad [4] to test the validity of the module.

This questionnaire contains 5 items created by Jamaludin Ahmad [4] given to 3 designated experts. The items in this questionnaire were based on Rusell's [11] view on the validity requirements of the module. The validity requirements of the modules are made in terms of Likert scale 1 to 5 . The selection of the Likert scale is to request the expert's approval of the statements regarding the validity of the module.

5. Data Analysis Technique:

The validity of the module is determined by calculating the percentage of experts consent. Individual expert approval percentage is calculated using the following formula:

$$
\frac{\text { Total Likert scale scores }}{\text { Maximum scores (25) }} \times 100 \%
$$

The mean percentage is calculated to get the percentage of experts consents for the module using the following formula:

$$
\frac{\text { Total percentage of expert approval }}{3 \text { experts }}
$$

Discussion:

Development of Manipulative Module of Algebraic Tiles:

This Manipulative Module of Algebraic Tiles was developed by researchers using algebraic tiles manipulative materials. Manipulative is a concrete object used to help students understand the concept [3]. This module was developed based on SMDM [15]. This module is designed for moderate- low Form Four students. The module contains seven units. Each unit contains related activities. This module is also accompanied with exercise questions at the end of each unit and the High Order Thinking Skills (HOTS) questions at the end of the module. To get clearer picture of the use of algebraic tiles for this topic, this module is also included with a website link that shows the use of algebraic tiles. Each learning theory used in the development of this module is implemented in the student's activities.

Constructivism Learning Theory sees individuals as active participants in constructing their own knowledge. There are four main features (1) cognitive exploration by emphasizing inquiry and hands- on and mind activities; (2) students have autonomy in forming their knowledge; (3) social interactions through learning together among students forming cognitive activities and (4) student- centered thinking, and students' views are important [17].

Piaget's Cognitive Theory [10] states that children will go through the same stages of development at different ages. Piaget divides cognitive development into four levels in order of age; (1) Motor Sensory Stage (since birth- 2 years); (2) Pre- Operation stage (2 years- 7 years); (3) Concrete Operation Stage (7 years11 years) and (4) Formal Operation Stage (11 years - 15 years). At the formal level of a child or teenager, it is possible to construct abstract thinking from the use of concrete materials to built new knowledge.

Bruner's Learning Theory [1] says learning is an active process of acquiring new knowledge. The stages of the teaching and learning process following Bruner are (1) Information Stage; (2) Transformation Stage and (3) Evolution Stage. Bruner emphasizes the concept of mathematical teaching and learning initiating with a concrete material to more abstract higher stages. Students should be exposed to active learning enabling students to form a steady and sustainable understanding [9].

The objectives of the Manipulative Module of Algebraic Tiles is as follows:

1. Medium to exchanges abstract concepts to concrete materials (algebraic tiles)

2. Expose the students to the use of algebraic tiles.

3. Attract the student's interest to the topic of Quadratic Expressions and Equations.

4. Change the student's perception of the topic of Quadratic Expressions and Equations.

5. Promote constructive learning.

2. The validity of the Manipulative Module of Algebraic Tiles:

The validity of the Manipulative Module of Algebraic Tiles content is endorsed by 3 experts. The approval percentage of first expert is $80 \%$, the second expert with $92 \%$ while the third expert with $88 \%$. The mean approval percentage of experts is $86.7 \%$. According to Sidek \& Jamaludin [15], the approval 
Citation: Rozita Mohamed Radzuan and Marzita Puteh. Development of Manipulative Module of Algebraic Tiles for Quadratic Expressions and Equations. Advances in Natural and Applied Sciences., 12(8): 33-35. DOI: 10.22587/anas.2018.12.8.6

percentage of experts who exceed $70 \%$ confirms high- level validation. In conclusion, the Manipulative Module of Algebraic Tiles has been certified by experts and has high validity.

Conclusion:

In conclusion, this study was conducted to develop Manipulative Module of Algebraic Tiles using concrete materials for Quadratic Expressions and Equations topic. The development of this module is required based on studies showing that many students made mistakes answering questions on the topics of Quadratic Expressions and Equations [13]. The use of algebraic tiles as a manipulative material showed improvements in understanding the concepts in various algebraic topics [3] and [2]. This module has also been tested on its validity and is ready to be tested for its reliability.

\section{REFERENCES}

[1] Bruner, I, 1966. Towards a theory of instruction. Cambridge, MA: Harvard University Press.

[2] Chappell, M.F., Struchens, M.E., 2017. Creating connections: Promoting algebraic thinking with concrete model. United States: ProQuest.

[3] Goins, K., 2001. Comparing the effects of visual and algebra tile manipulative methods on student skill and understanding polynomial multiplication. University of South Cardinal.

[4] Jamaludin Ahmad, 2016. Modul Motivasi Diri. Kuala Lumpur: Perpustakaan Negara Malaysia.

[5] Kementerian Pendidikan Malaysia, 2001. Buku Pembangunan Pendidikan Malaysia 2001- 2010.Kuala Lumpur, Malaysia: Penerbitan Kementerian Pendidikan Malaysia.

[6] Kementerian Pendidikan Malaysia, 2012. Laporan Kajian TIMSS dan PISA: Status Pencapaian Malaysia. Putrajaya, Malaysia: Penerbitan Kementerian Pendidikan Malaysia.

[7] Kementerian Pendidikan Malaysia, 2016. Laporan TIMSS 2015. Putrajaya, Malaysia: Penerbitan Kementerian Pendidikan Malaysia.

[8] Marzita Puteh, Nor'ain Mohd Tajudin, Mazlini Adnan \& Azrul Azwan Mohd Abdul Aziz. 2017. The Utilization of Bar Model Method in Year 5 Mathematics Learning Based on HOTS, International Journal of Advanced Biotechnology and Research (IJBR),8(3), 56-63.

[9] Muhamad Hafizhuddin Abdul Rahman and Marzita Puteh, 2016. Learning trigonometry using Geo Gebra Learning module: Are under achivers pupils motivated? AIP Conference Proceedings 1750, 04001; doi 10.1063/1.495486

[10] Piaget, J., 1964. Part 1 Cognitive Development in Children: Piaget Development and Learning. Journal of Research in Science Teaching, 2, 176-186. https://doi.org/10.1002/tea.3660020306

[11] Rusell, J. D. (1974). Modular Instruction: A guide to the design, Selection, Utilization and Evaluation of Modular Materials. United States. United States Publishing Company.

[12] Schlosser, T.K., 2010. Using algebra tiles to aid Students in factoring polynomials. Central Connecticut State University. Retrieved from http://www.researchgate.net/publication/49112169 Using algebra tiles to aid students in factoring poly nomials/amp\#ampshare

[13] Shankar Radah Krishna. 2015. Analisis Kesilapan dalam Pengembangan dan Pemfaktoran Ungkapan Aljabar dalam Kalangan Pelajar Tingkatan Empat. Universiti Pendidikan Sultan Idris. Retrived from http://eprints.usm.my/30409/1/SHANKAR_RADAH_KRISHNA24.pdf

[14] Sherman, M., 2011. An Examination of the Role of Technological Tools in Relation to the Cognitive Demand of Mathematical Tasks in Secondary Classrooms. University of Pittsburgh.

[15] Sidek, Mohd Noah., \& Jamaludin Ahmad., 2008. Pembinaan Modul.Bagaimana membina modul latihan dan modul akademik. (Kedua). Serdang: Penerbit Universiti Putra Malaysia.

[16] Site Hadijah Harun, Razali Hassan \& Tajol Anuar Md. Yunus, 2015. Mengenal pasti tahap KBAT iaitu menganalisis, menilai dan mencipta menggunakan peta pemikiran dalam subjek sains. Jurnal Penyelidikan Pendidikan, 16, 216-227.

[17] Tunku Badariah Tunku Ahmad, 2014. Between School Factors and Teacher Factors: What Inhibits Malaysian Science Teachers From Using ICT? The Malaysian Online Journal of Educational Technology, 2(1): 1-10. 